\title{
Tauopathy-induced retinal dysfunction in the P301S mutant human tau transgenic mouse
}

\author{
Nadia Mazzaro ${ }^{1}$, Erica Barini ${ }^{1}$, Michel Goedert ${ }^{2}$, Maria Grazia Spillantini ${ }^{3}$, Paolo Medini ${ }^{1}$, Laura Gasparini ${ }^{*}$ \\ From Molecular Neurodegeneration: Basic biology and disease pathways \\ Cannes, France. 10-12 September 2013
}

Intracellular inclusions made of microtubule-associated tau protein are a defining pathological hallmark of tauopathies, which include Alzheimer disease and familial frontotemporal dementia and parkinsonism linked to chromosome 17. Altered levels of tau protein have been detected in the retina and optic nerve of patients with glaucoma, suggesting that retina degeneration and tauopathies share similar pathogenic mechanisms. We have recently demonstrated that P301S mutant human tau (tau $\left.{ }_{\mathrm{P} 301 \mathrm{~S}}\right)$ mice develop tau filamentous inclusions and axonopathy in retinal ganglion neurons (RGCs), in the absence of neuronal loss or alterations in the outer retina. Moreover, we showed that tau $\mathrm{P}_{\mathrm{P} 301 \mathrm{~S}}$ transgenic retinal explants do not respond to neurotrophic stimuli in vitro. Here, we investigated the impact of tau pathology on RGC physiology in living animals and neurotrophin signaling pathways in vivo. In anesthetized 5 -month old wild type (WT) and tau ${ }_{\mathrm{P} 301 \mathrm{~S}}$ mice, we measured RGCs activity using pattern electroretinogram (pERG), which selectively detects $R G C$ response upon pattern light stimuli exposure. In transgenic tau $\mathrm{P}_{\mathrm{P} 301 \mathrm{~s}}$ mice the amplitude of both $\mathrm{P} 1$ positive and $\mathrm{N} 2$ negative components of pERG at saturating contrast and spatial frequency was significantly smaller than WT values. Furthermore, retinal acuity was significantly reduced

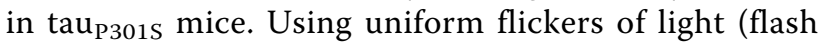
ERG), we measured the activity of the outer retina and found that outer retina response was preserved in tau $\mathrm{P}_{\mathrm{P} 301 \mathrm{~S}}$ mice. Neurotrophins, and especially brainderived neurotrophic factor (BDNF), are important modulators of neuronal survival and function in the brain and in the visual system. We therefore investigated the BDNF signaling pathway and found that BDNF signalling was altered in tau $\mathrm{P}_{\mathrm{P} 301 \mathrm{~S}}$ transgenic retinas. Our

${ }^{1}$ Neuroscience and Brain Technologies, Istituto Italiano di Tecnologia, Genova, Italy

Full list of author information is available at the end of the article results indicate that, in the tau $\mathrm{P}_{\mathrm{P} 01 \mathrm{~S}}$ mouse, tau pathology specifically impairs the activity of RGCs, without affecting the outer retina function and is associated with BDNF signalling alterations. Given the role of BDNF in synaptic plasticity, these data suggest that mild levels of tau pathology are sufficient to trigger significant neuronal dysfunction possibly through alteration of neurotrophic signalling. Funded by a grant of Compagnia di San Paolo awarded to LG.

\section{Authors' details}

${ }^{1}$ Neuroscience and Brain Technologies, Istituto Italiano di Tecnologia, Genova, Italy. ${ }^{2}$ MRC Laboratory of Molecular Biology, Cambridge, UK. ${ }^{3}$ Cambridge Centre for Brain Repair, University of Cambridge, UK.

Published: 4 October 2013

doi:10.1186/1750-1326-8-S1-P57

Cite this article as: Mazzaro et al:: Tauopathy-induced retinal

dysfunction in the P301S mutant human tau transgenic mouse. Molecular Neurodegeneration 2013 8(Suppl 1):P57.

Submit your next manuscript to BioMed Central and take full advantage of:

- Convenient online submission

- Thorough peer review

- No space constraints or color figure charges

- Immediate publication on acceptance

- Inclusion in PubMed, CAS, Scopus and Google Scholar

- Research which is freely available for redistribution
C Biomed Central

C 2013 Mazzaro et al; licensee BioMed Central Ltd. This is an Open Access article distributed under the terms of the Creative Commons Attribution License (http://creativecommons.org/licenses/by/2.0), which permits unrestricted use, distribution, and reproduction in any medium, provided the original work is properly cited. 